\title{
Tropical terrestrial model ecosystems for evaluation of soil fauna and leaf litter quality effects on litter consumption, soil microbial biomass and plant growth
}

\author{
Bernhard Förster ${ }^{(1)}$, Marcos Garcia ${ }^{(2)}$, Hubert Höfer ${ }^{(3)}$, Edward Morgan ${ }^{(4)}$ and Jörg Römbke ${ }^{(1)}$ \\ (1)ECT Oekotoxikologie GmbH, Böttgerstrasse 2-14, D-65439 Flörsheim, Germany. E-mail: b-foerster@ect.de, j-roembke@ect.de \\ (2)Embrapa Amazônia Ocidental, Caixa Postal 319, CEP 69011-970 Manaus, AM, Brazil. E-mail: mvbgarcia@gmail.com ${ }^{(3)}$ Staatliches Museum \\ für Naturkunde Karlsruhe, Erbprinzenstrasse 13, D-76133 Karlsruhe, Germany. E-mail: hubert.hoefer@smnk.de ${ }^{(4)}$ University of Glamorgan, \\ School of Applied Sciences, Pontypridd CF37 1DL, United Kingdom. E-mail: emorgan@glam.ac.uk
}

\begin{abstract}
The aim of this work was to evaluate whether terrestrial model ecosystems (TMEs) are a useful tool for the study of the effects of litter quality, soil invertebrates and mineral fertilizer on litter decomposition and plant growth under controlled conditions in the tropics. Forty-eight intact soil cores (17.5-cm diameter, 30-cm length) were taken out from an abandoned rubber plantation on Ferralsol soil (Latossolo Amarelo) in Central Amazonia, Brazil, and kept at $28^{\circ} \mathrm{C}$ in the laboratory during four months. Leaf litter of either Hevea pauciflora (rubber tree), Flemingia macrophylla (a shrubby legume) or Brachiaria decumbens (a pasture grass) was put on top of each TME. Five specimens of either Pontoscolex corethrurus or Eisenia fetida (earthworms), Porcellionides pruinosus or Circoniscus ornatus (woodlice), and Trigoniulus corallinus (millipedes) were then added to the TMEs. Leaf litter type significantly affected litter consumption, soil microbial biomass and nitrate concentration in the leachate of all TMEs, but had no measurable effect on the shoot biomass of rice seedlings planted in top soil taken from the TMEs. Feeding rates measured with bait lamina were significantly higher in TMEs with the earthworm $P$. corethrurus and the woodlouse $C$. ornatus. TMEs are an appropriate tool to assess trophic interactions in tropical soil ecossistems under controlled laboratory conditions.

Index terms: Brachiaria decumbens, Flemingia macrophylla, Hevea pauciflora, diplopods, earthworms, isopods.

\section{Efeitos de fauna de solo e qualidade de liteira sobre o consumo, biomassa microbiana e crescimento de plantas em modelo de ecossistemas terrestres tropicais}

\begin{abstract}
Resumo - O objetivo deste trabalho foi avaliar o modelo de ecossistema terrestre (TME) como ferramenta para o estudo dos efeitos da qualidade da liteira, de invertebrados do solo e da fertilização mineral na decomposição da liteira e no crescimento das plantas em condições controladas. Foram coletados quarenta e oito cilindros de solo intacto (Latossolo Amarelo) de17,5 cm de diâmetro e $30 \mathrm{~cm}$ de comprimento em um seringal abandonado na Amazônia Central brasileira e mantidos a $28^{\circ} \mathrm{C}$ em laboratório, por quatro meses. Folhas da liteira de Hevea pauciflora (seringueira), ou de Flemingia macrophylla (leguminosa arbustiva) ou de Brachiaria decumbens (gramínea) foram colocadas na superfície do solo em cada TME. Em seguida, foram adicionados aos TMEs, cinco espécies de minhocas: Pontoscolex corethrurus ou Eisenia fetida; isópodes: Porcellionides pruinosus ou Circoniscus ornatus, e o diplópode Trigoniulus corallinus. $\mathrm{O}$ tipo de liteira afetou de forma significativa o consumo, a biomassa microbiana e a concentração de nitrato no líquido percolado de todos os TMEs, mas não apresentou efeito mensurável sobre a biomassa da parte aérea de mudas de arroz, plantadas em solo retirado da superfície dos TMEs. As taxas de alimentação da fauna edáfica, medidas por meio de lâminas-isca, foram signifitivamente mais altas nos TMEs com a minhoca $P$. corethrurus e com o isópode $C$. ornatus. O método TME se mostrou uma ferramenta apropriada para avaliar intrações tróficas em ecossistemas de solo tropical sob condições controladas de laboratório.
\end{abstract}

Termos para indexação: Brachiaria decumbens, Flemingia macrophylla, Hevea pauciflora, diplópodes, minhocas, isópodes.

\section{Introduction}

Terrestrial model ecosystems (TME) are used to study processes in the soil by selectively maintaining part of the natural spatial, temporal and genetic heterogeneity (Edwards \& Bohlen, 1996), while controlling selected variables and observing the input and output of the system. Based on the early work of Van Voris et al. (1985), Knacker et al. (2004) developed a terrestrial model ecosystem (TME) using 
intact soil cores. These TMEs are characterized by a undisturbed soil structure and by the maintenance of autochthonous soil organisms. Since Morgan and Knacker (1994) published a classification of the various types of TMEs, such enclosed model ecosystems have increasingly been used in ecological research (Förster et al., 1996; Sheppard, 1997; Kampichler et al., 2001). More recently, the intact-soil-core approach has been successfully used in an wide experiment to assess its applicability to test potentially harmful substances at the ecosystem level (Förster et al., 2004; Knacker et al., 2004; Römbke et al., 2005b).

The restoration of abandoned plantations in Central Amazonia is a main goal to achieve sustainable land use and to prevent the ongoing transformation of native forest into arable land. The soils of these abandoned plantations are characterized by severe nutrient limitations, especially with regard to phosphorus (Lehmann et al., 2001). To improve soil properties, such as organic matter content, and to increase soil fertility, plant litter management strategies that focus on litter quality and soil fauna abundance have been proposed (Martius et al., 2001). Such ecological (non-technological) approaches contradict the increasing use of mineral fertilizers and plant protection products, which may negatively affect soil organisms and thus litter decomposition. The environmental risk assessment schemes applied in the registration of pesticides are usually based on temperate conditions and do not take into consideration the different physical-chemical (e.g. high temperature, low $\mathrm{pH}$ ) and biological (soil organism species) conditions in the tropics (Römbke et al., 2005a).

The aim of this work was to evaluate whether terrestrial model ecosystems (TMEs) are a useful tool for the study of the effects of litter quality, soil invertebrates and mineral fertilizer on litter decomposition and plant growth under controlled conditions in the tropics.

\section{Materials and Methods}

Sixty intact soil cores $(30-\mathrm{cm}$ depth, 17.5-cm diameter) were taken by means of a steel extraction tube from an abandoned, 20-year-old rubber (Hevea pauciflora) plantation within the experimental site of Embrapa Amazônia Ocidental, situated $30 \mathrm{~km}$ outside Manaus, AM, Brazil. Forty-eight out of the sixty soil cores were selected for the test according to the criteria determined by Knacker et al. (2004). Each TME test unit consisted of an intact soil core encased by a high-density polyethylene tube and placed on a Büchner funnel with a thin layer of inert gauze to fit between the drilled holes of the funnel and the bottom of the soil core (Knacker et al., 2004). Polyvinyl-chloride tubing connected the funnel to a wide-neck $1,000-\mathrm{mL}$ polyethylene bottle to collect the leachate. TMEs were irrigated with demineralized water $\left(20 \mathrm{~mL} \mathrm{TME}^{-1}\right.$, poured onto the litter layer) three times per week to keep the soil moisture within the range of 30 to $35 \%$ (dry weight basis).

The TMEs were placed in movable wooden carts (eight TMEs per cart) and kept in the laboratory at an average air temperature of $28^{\circ} \mathrm{C}$ (from 26 to $31^{\circ} \mathrm{C}$ ) and at 150-300 lx for 12 hours day ${ }^{-1}$ for a total period of four months, including an initial acclimatization period of four weeks without added animals. A transparent open-top cylinder made of PVC was attached to the upper end of the TME to prevent soil organisms from escaping.

The soil of the rubber plantation was classified as Ferralsol (Latossolo Amarelo), with a clay texture (81\% clay, $9 \%$ sand and $10 \%$ silt), a pH $\left(\mathrm{H}_{2} \mathrm{O}\right)$ of 4.0 and low organic matter content $\left(1.0-2.0 \% \mathrm{C}_{\text {org }}, 0.1-0.2 \% \mathrm{~N}_{\text {total }}\right.$, $1.9-3.5 \%$ organic matter). The rubber trees had been planted 20 years ago on pasture established after the primary forest had been cut and burned in 1960. This area did not receive any fertilizer or pesticide and was not subjected to any soil management practices at least during the last ten years.

The natural leaf litter layer was removed from the TME surface and replaced by $10 \mathrm{~g}$ (fresh weight) of senescent leaves from either rubber trees (H. pauciflora) grown and sampled in the TME extraction area, or from senescent leaves of a shrubby legume (Flemingia macrophylla) grown in neighbouring agroforestry systems (Table 1 ). The third litter type was hay from an abundant pasture grass (Brachiaria decumbens). The water content (\% of dry weight) ofthelittermaterialwas of $78 \%$ (F.macrophylla), 56\% (H. pauciflora) and 75\% (B. decumbens). The leaves were characterized by different $\mathrm{C} / \mathrm{N}$ ratios, and increased from 13.9 ( $F$. macrophylla) to 17.3 (B. decumbens) and 32.6 (H. pauciflora). At the end of the test period, the remaining leaf litter was removed from the soil surface, dried at $60^{\circ} \mathrm{C}$ until constant mass and weighed to calculate the overall mass loss during the experiment. 
Five species of soil invertebrates belonging to taxa that are known to be important for litter decomposition in tropical regions (Swift et al., 1979; Höfer et al., 2001) were selected as test organisms: Trigoniulus corallinus Gervais, 1847, a millipede species that acts mainly as a litter comminutor; two isopod species that feed on litter and debris at the soil surface, Porcellionides pruinosus Brandt, 1833 and Circoniscus ornatus Verhoeff, 1941; and two earthworm species, Eisenia fetida Savigny, 1826 and Pontoscolex corethrurus Müller, 1857, which represent epigeic and endogeic forms respectively. Animals of three species were combined into either a laboratory grouping (woodlice and earthworms bred in laboratory mass cultures for ecotoxicological testing) or a field grouping (collected in the field) (Table 1). The compost worm E. fetida and the isopod P. pruinosus have been chosen for the laboratory grouping since these species are typical test organisms, often used in standardized terrestrial tests (Römbke et al., 2005a,b). Five adult specimens of each species of the two groupings were inserted into each TME at the start of the test (Table 1), i.e. at the end of the four-week acclimatization phase of the TMEs in the laboratory. The specimens of the same species had approximately the same size. While the age of the animals from lab cultures could be estimated, the age of the animals collected in the field was completely unknown. The surface of each TME was checked weekly for dead invertebrates. After four weeks, dead isopods and diplopods were replaced with the same number of new specimens. At the end of the test period, all soil

Table 1. Plant and animal species used in the TME experiments.

\begin{tabular}{|c|c|}
\hline Test group & Soil invertebrate species/plant species \\
\hline Laboratory grouping & $\begin{array}{l}\text { Eisenia fetida Savigny, } 1826 \text { (Oligochaeta, } \\
\text { Lumbricidae) }^{(\mathrm{a})} \\
\text { Porcellionides pruinosus } \text { Brandt, } 1833 \text { (Isopoda, }_{\text {Porcellionidae) }}{ }^{(\mathrm{a})} \\
\text { Trigoniulus corallinus Gervais, } 1847 \text { (Diplopoda, }_{\text {Trigoniulidae) }^{(\mathrm{b})}}\end{array}$ \\
\hline Field grouping & $\begin{array}{l}\text { Pontoscolex corethrurus Müller (Oligochaeta, } \\
\text { Glossoscolecidae) } \\
\text { Circoniscus ornatus Verhoeff, } 1941 \text { (Isopoda, } \\
\text { Scleropactidae) } \\
\text { Trigoniulus corallinus Gervais, } 1847 \text { (Diplopoda, }_{\text {Trigoniulidae) }^{(\mathrm{b})}}\end{array}$ \\
\hline \multicolumn{2}{|l|}{ Plant species } \\
\hline Rubber leaves & $\begin{array}{l}\text { Hevea pauciflora (Spruce ex Benth.) Müll. Arg. } \\
\text { (Euphorbiaceae) }^{(\mathrm{b})}\end{array}$ \\
\hline Grass (hay) & Brachiaria decumbens Stapf (Paniceae) $)^{(\mathrm{b})}$ \\
\hline Legume leaves & $\begin{array}{l}\text { Flemingia macrophylla (Willd.) Merr. } \\
{\text { (Fabaceae })^{(\mathrm{b})}}\end{array}$ \\
\hline
\end{tabular}

(a)Bred in laboratory mass cultures; ${ }^{(b)}$ collected in the field. invertebrates were collected by hand from the entire soil cores and counted.

Twenty-four out of the 48 TMEs were fertilized with a dilution of the commercially available liquid fertilizer Ouro Verde (Bunge Fertilizer - Ouro Verde). A volume of $50 \mathrm{~mL}$ of diluted fertilizer $(4 \mathrm{~mL}$ fertilizer and $46 \mathrm{~mL}$ demineralized water) was applied per TME to achieve nutrient application rates comparable to local recommendations: $\mathrm{N}$ (urea, $115 \mathrm{~kg} \mathrm{ha}^{-1}$ ), $\mathrm{P}_{2} \mathrm{O}_{5}$ (46.9 $\left.\mathrm{kg} \mathrm{ha}^{-1}\right), \mathrm{K}_{2} \mathrm{O}\left(115 \mathrm{~kg} \mathrm{ha}^{-1}\right), \mathrm{MgO}\left(18.7 \mathrm{~kg} \mathrm{ha}^{-1}\right)$; Zn $\left(1.25 \mathrm{~kg} \mathrm{ha}^{-1}\right)$ and $\mathrm{B}\left(0.63 \mathrm{~kg} \mathrm{ha}{ }^{-1}\right)$. Each non-fertilized TMEs received $50 \mathrm{~mL}$ water instead of diluted fertilizer.

To assess feeding activity in the soil, the bait lamina method (von Törne, 1990; Kratz, 1998; Römbke et al., 2006) was applied. Bait lamina are plastic strips of $120 \times 6 \times 1 \mathrm{~mm}$ with a series of 16 holes of $1.5 \mathrm{~mm}$ diameter in the lower part $(85 \mathrm{~mm})$. The holes were filled with bait material made of powdered cellulose $(60 \%)$, agar $(20 \%)$ and $20 \%$ of finely ground leaves of Pueraria phaseoloides Roxb., a common legume cover crop of the Amazonian region. Four bait lamina stripes per TME were inserted into the soil ten days before the end of the three-month experimental period. Feeding was assessed by counting the number of fed baits (empty holes).

At the end of the test, the top soil layer $(0-5 \mathrm{~cm})$ of each TME was completely removed, sieved $(4 \mathrm{~mm})$ and mixed thoroughly. Aliquots of $40 \mathrm{~g}$ dry mass equivalent were used to measure the substrate-induced respiration (SIR) after adding glucose (mixed with talcum at a ratio of $1: 5 \mathrm{w} / \mathrm{w}$ ) at an optimal concentration (6 $\mathrm{mg} \mathrm{g}^{-1}$ soil dry weight) according to International Organization for Standardization (1997). Microbial biomass carbon $\left(\mathrm{C}_{\text {mic }}\right)$ was estimated from the initial stable respiration response by applying a factor of 40 (Anderson \& Domsch, 1978) with an automatic soil respiration measuring device based on infrared gas analysis (Förster et al., 2006a).

For the seedling growth test, aliquots of $130 \mathrm{~g}$ dry mass equivalent of sieved top soil ( 0 to $5 \mathrm{~cm}$ depth) taken from each TME soil core at the end of the test period were filled into plant pots $(200 \mathrm{~mL}$ polystyrene beakers with perforated bottom). Three seedlings of rice (Oryza sativa, cv. Primavera), which had been pre-germinated for two days on moist filter paper to achieve a radicle of approximately 3 to $5 \mathrm{~mm}$ length, were planted into each pot. The pots were placed 
randomly within an area of $1 \mathrm{~m}^{2}$ in the greenhouse, and seedlings were left to grow for 28 days at ambient temperature $\left(24\right.$ to $\left.35^{\circ} \mathrm{C}\right)$. The pots, one per TME, were irrigated with demineralized water every two days. At day 28, the seedlings were harvested and shoot length and shoot dry weight $\left(60^{\circ} \mathrm{C}\right.$ until constant weight) was determined.

At the end of the test period, $250 \mathrm{~mL}$ of demineralized water were applied during two hours to each TME soil core in portions of $50 \mathrm{~mL}$. Based on the $240-\mathrm{cm}^{2}$ soil surface area, this volume corresponds to a precipitation of about $10 \mathrm{~mm}$. Leachate was collected after 24 hours and stored immediately in a freezer for subsequent analyses of nitrate and ammonium via flow-injection analysis method (FIA).

The design of the experiment was a $2 \times 2 \times 3$ factorial distribution of 12 separate treatments with four replicates each, comprising a total of 48 experimental runs. The statistical analysis for the overall experiment, including all the endpoints, was an analysis of variance (Morgan, 1991) carried out using SPSS in which all main effects, two-factor and three-factor interactions were assessed. Homogeneity of within-group variance was assessed by Levene's test. Where significant factors were evident, Tukey's Honestly Significant Difference (HSD) post-hoc test was applied to the "litter" factor to examine which particular means were significantly different, at $5 \%$ of probability.

\section{Results and Discussion}

The TME approach was applicable to the tropical conditions without problems. The extraction of intact soil cores from the extremely clayey Ferralsol soils via the extraction tube was feasible without any modifications of the procedure. Also, the tropical conditions caused no problems during the incubation period.

Mass loss or consumption of F. macrophylla litter was nearly twice the one of $B$. decumbens and more than twice the one of $H$. pauciflora litter. Differences between the species were highly significant $(p<0.01)$. Differences in mass loss between the soil fauna treatments were not significant (Table 2). Fertilization had a significant positive effect only on the consumption of B. decumbens litter (Figure 1).

Leaf litter mass loss differed significantly between the three plant species, indicating the influence of litter quality. While in temperate ecosystems earthworms are often the most important organisms governing organic matter breakdown (Edwards \& Bohlen, 1996), in the tropics not only earthworms but also millipedes and woodlice seem to be the main driving force for the decomposition process (Anderson et al., 1983; Tian et al., 1992; ; Gonzalez \& Seastedt, 2001). The strong influence of soil macrofauna on decomposition rates in Central Amazonian forests and plantations has been shown in several decomposition experiments with litterbags (Höfer et al., 2001; Kurzatkowski et al., 2004).

In our experiment, the millipede $T$. corallinus represented the major part of the soil fauna biomass in the TMEs. This millipede, present in both groupings (laboratory and field), was a very active litter consumer,

Table 2. Litter consumption (mass loss in \% of initial mass) of three plant species during four months in TMEs harbouring two different groupings of soil fauna ${ }^{(1)}$.

\begin{tabular}{|c|c|c|c|}
\hline Soil fauna grouping & $\begin{array}{c}\text { Flemingia } \\
\text { macrophylla }\end{array}$ & $\begin{array}{c}\text { Hevea } \\
\text { pauciflora }\end{array}$ & $\begin{array}{l}\text { Brachiaria } \\
\text { decumbens }\end{array}$ \\
\hline & \multicolumn{3}{|c|}{ Laboratory grouping } \\
\hline $\begin{array}{l}\text { E. fetida, } P \text {. pruinosus, } \\
\text { T. corallinus }\end{array}$ & $73.3 \pm 7.6 \mathrm{a}$ & $33.8 \pm 4.1 \mathrm{~b}$ & $41.4 \pm 7.3 \mathrm{c}$ \\
\hline & \multicolumn{3}{|c|}{ Field grouping } \\
\hline $\begin{array}{l}\text { P. corethrurus, } \\
\text { C. ornatus, } T \text {. corallinus }\end{array}$ & $78.3 \pm 6.1 \mathrm{a}$ & $30.4 \pm 10.2 b$ & $43.9 \pm 11.2 \mathrm{c}$ \\
\hline
\end{tabular}

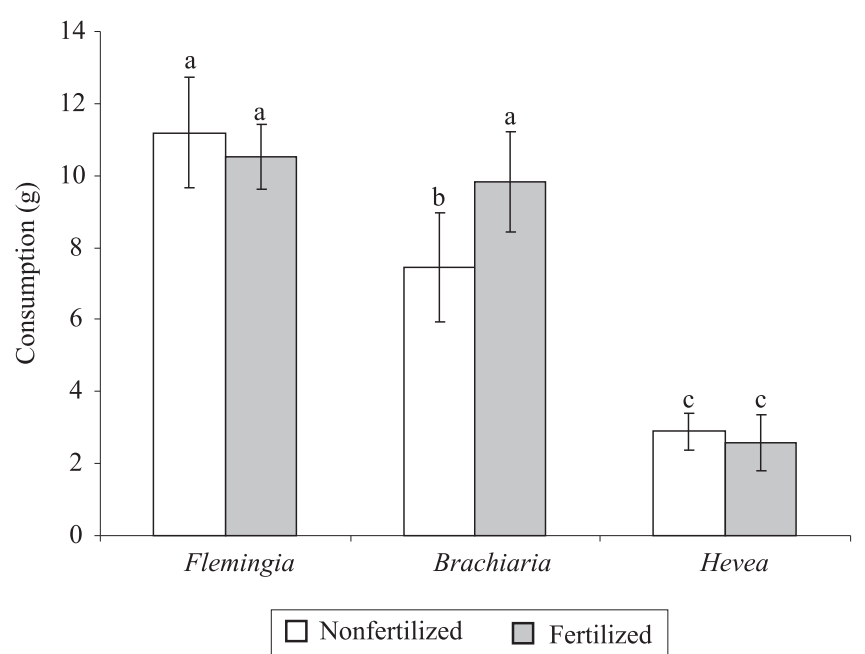

Figure 1. Consumption of leaf litter from Flemingia macrophylla, Brachiaria decumbens and Hevea pauciflora in fertilized and non-fertilized TMEs. Mean values and standard deviation $(\mathrm{n}=8)$. Different letters indicate significant differences at $5 \%$ of probability level between plant litter species or fertilization status. 
produced considerable amounts of faeces, and clearly preferred to feed on the legume litter. The latter may be due to a better palatability in comparison to the grass and the rubber tree litter because of the low lignin content and the low $\mathrm{C} / \mathrm{N}$ ratio of the leguminous litter. Pobozsny et al. (1992) observed that T. corallinus (cited as Trigoniulus lumbricinus) was differently attracted by different litter types. In their experiments, a higher feeding activity in Coffea and Hibiscus than in Panicum (grass) leaves was observed. The feeding of $T$. corallinus is assumed to be one reason why the breakdown of three litter types did not differ quantitatively between the laboratory and the field groupings, although it cannot be ruled out that the high mortality of these animals may have masked existing differences.

Selective feeding is also well known for earthworms. For example, typical surface feeders from temperate regions such as Lumbricus terrestris seem to prefer nitrogen-rich food material (Förster et al., 1996). Although $P$. corethrurus is considered an endogeic species, it may also attack leaf litter on the soil surface either directly by ingesting small parts or indirectly by increasing microbial activity through deposition of casts on the soil surface. It could be assumed that, due to a low $\mathrm{C} / \mathrm{N}$ ratio, grass and leguminous litter may be preferred by $P$. corethrurus. The fast decomposition of leguminous litter described for other tropical ecosystems, e.g. for crop sites in India (Arunachalam et al., 2003), may also indicate its high attractiveness to earthworms. However, the quantitative role of the $P$. corethrurus earthworm in the breakdown of leaf litter in the TMEs is not clear. The low consumption of rubber tree litter was not surprising, since $H$. pauciflora is an example of a type of litter with low palatability due to the high lignin/ $\mathrm{N}$ ratio, which indicates low litter decomposability (Aerts, 1997). It has also been shown in mesocosm tests that the decomposition of Hevea brasiliensis litter was not enhanced by P. corethrurus after 97 days (Araujo et al., 2004). Moreover, toxic substances present in the leaves may have influenced the feeding preferences, as has been shown for earthworms by Chaudhuri et al. (2003).

Woodlice, millipedes and earthworms had been chosen as representatives of the most important decomposer soil fauna in the plantations (Höfer et al., 2001), and because most of the naturally occurring isopods and diplopods would have escaped during soil core extraction, an attempt to increase the level of standardization of the TMEs was also made by adjusting the number of soil invertebrates.

The isopods and diplopods added to the TMEs were actively moving around and feeding on the leaf litter. The native earthworm species $P$. corethrurus burrowed in the soil, whereas the composting worm E. fetida remained mainly on the soil surface, underneath the litter material in the layer rich in diplopod faeces. A relatively high mortality of the added invertebrates was observed during the test: $78-87 \%$ for the millipede T. corallinus, $42-73 \%$ for the isopod $C$. ornatus and $64-75 \%$ for the isopod P. pruinosus. The mortality of the native earthworm species $P$. corethrurus (25-53\%) was lower in comparison to E. fetida (45-68\%). Neither litter type nor fertilization had a significant effect on the mortality of these organisms (Table 3 ).

The highest mortality (78-87\%) was detected for the millipede T. corallinus, which is known to be sensitive to body water losses (Shukla \& Tripathi, 1985). The mortality was also high for the isopod species. Isopods are known to be sensitive to water loss and therefore often use shelters to hide. Due to the limited size of a TME, no such shelters were provided.

The reasons for the observed mortality remained unclear. It is assumed that variable soil and litter moisture during the trial has affected survival. The fact that the three plant litter types may not have been the preferred food source may have also contributed to the mortality. Ashwini \& Sridhar (2005) have shown that the production of fecal pellets from a tropical millipede was higher on mixed litter when compared to mono litter. Other reasons could be the age, the physiological stage and health of the individuals at the start of the test. These parameters were mostly unknown, even for the two species bred in mass cultures.

Table 3. Mean mortality \pm standard deviation (\%) of soil organisms in intact soil core TMEs with three litter types within a three-month trial $(\mathrm{n}=8)^{(1)}$.

\begin{tabular}{lcccc}
\hline Soil fauna species & $\begin{array}{c}\text { Flemingia } \\
\text { macrophylla }\end{array}$ & $\begin{array}{c}\text { Hevea } \\
\text { pauciflora }\end{array}$ & $\begin{array}{c}\text { Brachiaria } \\
\text { decumbens }\end{array}$ & $\begin{array}{c}\text { Overall } \\
\text { mean }\end{array}$ \\
\hline Trigoniulus corallinus & $86.7 \pm 6.9$ & $83.0 \pm 13.1$ & $77.5 \pm 14.0$ & 82.4 \\
Circoniscus ornatus & $67.8 \pm 24.6$ & $73.0 \pm 21.4$ & $42.3 \pm 24.9$ & 61.0 \\
Porcellionides pruinosus & $72.9 \pm 20.9$ & $74.5 \pm 16.5$ & $63.9 \pm 10.5$ & 70.4 \\
Eisenia fetida & $67.5 \pm 45.3$ & $65.0 \pm 35.1$ & $45.0 \pm 38.2$ & 59.2 \\
Pontoscolex corethrurus & $25.0 \pm 20.7$ & $35.0 \pm 33.4$ & $52.5 \pm 33.7$ & 37.5 \\
\hline (1) Data from fertilized and non-fertilized TMEs with the same litter type
\end{tabular}
were combined, since they were not significantly different. 
The mortality of the native earthworm species $P$. corethrurus was lower in comparison to $E$. fetida. This is not very surprising, since $P$. corethrurus is an endogeic species, well adapted to the tropics' acid soils used in the experiment (Römbke et al., 1999), while E. fetida is an epigeic species, restricted to sites rich in organic matter and that prefers neutral to slightly acidic soils (Römbke et al., 2005a). Consequently, it was observed in the TME experiment that $E$. fetida did not enter the soil, but remained on the surface, preferably in the diplopods' faeces layer. A similar behaviour has been observed in laboratory tests with this species, where both species showed high biomass losses in natural tropical soil (about $30 \%$ for $E$. fetida and about $20 \%$ for $P$. corethrurus), but no mortality occurred within 14 days (Garcia, 2004).

Further investigations are needed to clarify whether a refined control of the microclimatic conditions, e.g. by irrigating the soil cores more frequently and via special rain heads (Knacker et al., 2004), and by using mixed litter material and individuals from synchronized cultures (Jänsch et al., 2005), could help reduce mortality of the soil fauna introduced into TMEs.

Bait lamina feeding rates showed a high variability within and between the single TMEs. The mean feeding rate in TMEs was significantly lower for $B$. decumbens litter than it was for the other two species (Figure 2).

The overall feeding on baits was low when compared to feeding under field conditions (Römbke et al., 2006) and may also be a result of the partly low soil moisture. The higher feeding rates in TMEs with field fauna are assumed to be caused mainly by the presence of the endogeic earthworm

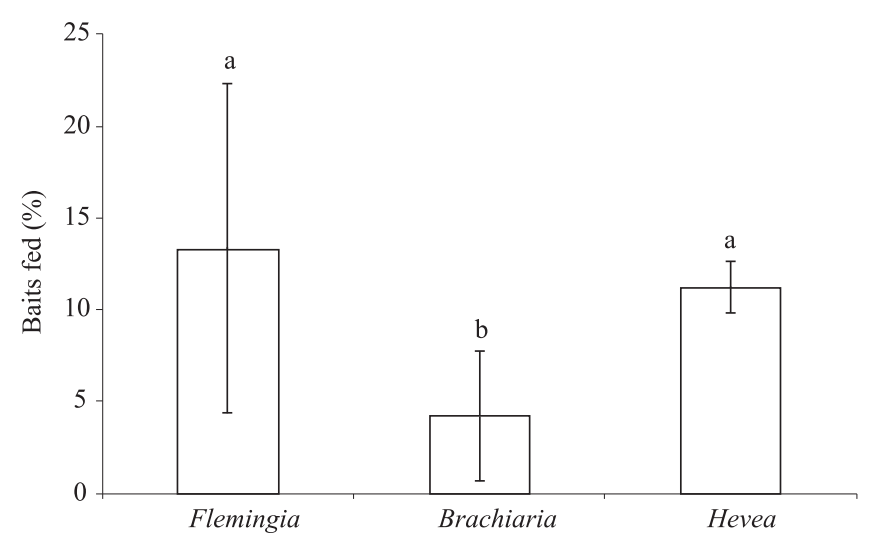

Figure 2. Bait lamina baits fed during 10-day exposure in TMEs containing leaf litter from either Flemingia macrophylla, Brachiaria decumbens or Hevea pauciflora. Mean and standard deviation $(\mathrm{n}=16)$. Different letters indicate significant differences at $5 \%$ of probability.
P. corethrurus, since this mineral-dwelling species is most closely in contact with the baitmaterial. The increased average feeding activity observed in the TMEs containing rubber tree litter indicates that the animals preferred the bait material in comparison to these leaves, probably due to their high $\mathrm{C} / \mathrm{N}$ ratio and low palatability. Feeding activities, as determined through the bait lamina method, did not correspond to the results obtained from decomposition measurements using litterbags (Römbke et al., 2006). Therefore, this new method reveals additional aspects of the function of soil invertebrates in soil ecosystems.

Based on substrate-induced respiration (SIR) measurements, the microbial biomass in soil from TMEs that contained B. decumbens litter was of $438 \mathrm{mg} \mathrm{C}_{\mathrm{mic}} \mathrm{g}^{-1}$ soil on average and significantly higher when compared to TMEs with $H$. pauciflora $\left(271 \mathrm{mg} \mathrm{C}_{\text {mic }} \mathrm{g}^{-1}\right.$ soil) and F. macrophylla litter (313 $\mathrm{mg} \mathrm{C}_{\text {mic }} \mathrm{g}^{-1}$ soil) (Figure 3). All other factors and factor interactions had no significant effects on SIR.

The soil microbial biomass measured in the top soil layer of the TMEs was in the range reported for this region by other authors (Feigl et al., 1995; Kurzatkowski et al., 2004; Martius etal., 2004). However, care must be taken if microbial biomass is calculated from SIR, since the conversion factors published in the literature (Anderson \& Domsch, 1978; Kaiser et al., 1992) are based on relationships observed in soils from temperate regions. It cannot be ruled out that, for tropical soils, the relationship between respiration and biomass differs from that of temperate regions. For our purpose, i.e. a comparison between treatments on a relative scale, the absolute level of the conversion factor is negligible.

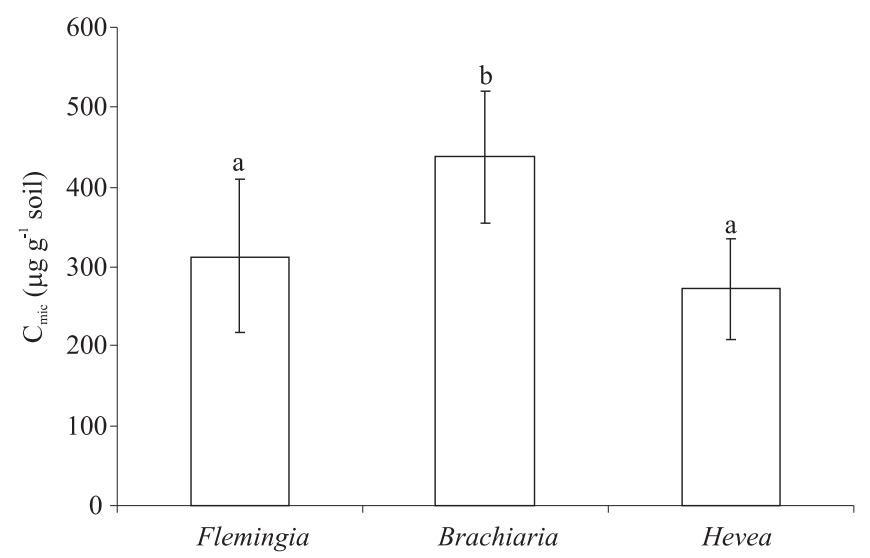

Figure 3. Soil microbial biomass carbon $\left(\mathrm{C}_{\text {mic }}\right)$ from TMEs with leaf litter from Flemingia macrophylla, Brachiaria decumbens and Hevea pauciflora. Mean and standard deviation $(\mathrm{n}=16)$. Different letters indicate significant differences at $5 \%$ of probability. 
The increased SIR biomass observed in the TMEs with grass litter may be caused by nutrients that were leached out of the grass litter via irrigation, or transferred from litter to soil through fungal hyphae (Lindahl \& Olsson, 2004). The grass litter was prepared from freshly cut grass, which usually contains more nutrients than senescent leaves. McMahon et al. (2005) have shown that the soluble fraction of grass straw promoted microbial growth in bulk soil. Also, the faeces from soil invertebrates feeding on the grass litter could be responsible for the increased respiration (Förster et al., 2006b). Similar effects on SIR of grass litter (hay) exposed on the soil surface have been reported earlier (Förster et al., 1995). The nutritional quality of the litter is known to influence the activity of the microbial biomass (Monteiro \& Gama-Rodriguez, 2004). For example, leaching of water-soluble $P$ from leaf litter can increase the soil biomass phosphorous (Ofori-Frimpong \& Rowell, 1999). Such a source of P may particularly be important for soils from the investigated area that are usually P-limited (Lehmann et al., 2001).

All plants grew healthy and with no visible damages, such as chlorosis or wilted leaves. Fertilization significantly increased the shoot length and dry mass of the rice seedlings by 13 and $32 \%$ respectively. In TMEs with laboratory fauna, the effect of fertilization was stronger (had significant interaction) (Figure 4). Litter type had neither an effect on seedling length nor on biomass.

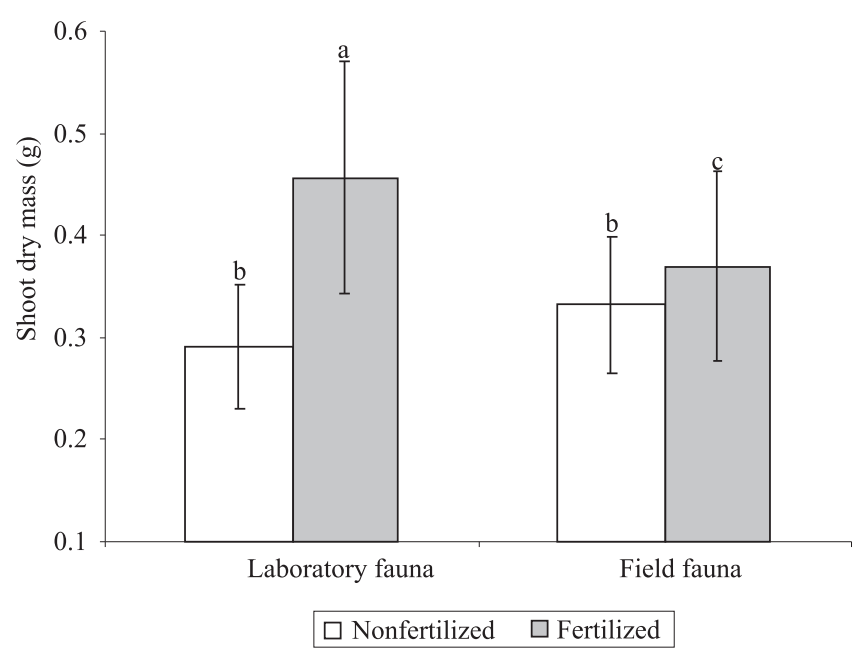

Figure 4. Shoot dry mass of rice seedlings grown for 28 days in soil of TMEs harbouring either laboratory fauna or field fauna, either fertilized or not. Mean values and standard deviation $(\mathrm{n}=12)$. Different letters indicate significant differences at $5 \%$ of probability between fauna grouping or fertilization status.
While the application of mineral fertilizer clearly enhanced plant growth, no effect was observed on this endpoint in any of the other factors. Due to the dimensions of the TMEs, the experimental period of three months in which soil invertebrates could feed on leaf litter may be too short a time to affect the nutrient status of the soil in TMEs in such a way that it would significantly enhance plant growth. However, the increased nitrate concentration observed in the leachate from TMEs containing F. macrophylla litter showed that the litter type did have a measurable but transient impact on the soil nutrient status. The reason why this effect was not accompanied by an increased plant biomass may indicate that nitrate was not the limiting factor for plant growth in this soil. The latter is in accordance with the observation that soils in the Amazon region are characterized by phosphorous rather than nitrate limitations (Lehmann et al., 2001).

The concentrations of nitrate and ammonium in the leachates from the fertilized TMEs were significantly higher $\left(2.9 \pm 1.6 \mathrm{mg} \mathrm{L}^{-1}\right.$ and $41.5 \pm 17.1 \mathrm{mg} \mathrm{L}^{-1}$ respectively) in comparison to the non-fertilized TMEs $\left(28.3 \pm 14.1 \mathrm{mg} \mathrm{L}^{-1}\right.$ and $1.05 \pm 1.32 \mathrm{mg} \mathrm{L}^{-1}$ respectively). The nitrate concentration in the leachates of TMEs with F. macrophylla litter was significantly higher $(\mathrm{p}<0.05)$ when compared to the two other litter types. The soil fauna grouping had no significant effect on nitrate and ammonium concentration in the leachate.

\section{Conclusions}

1. TME approach represents a potential alternative to investigate ecosystem-level endpoints in small-scale laboratory tests under standardized tropical conditions.

2. No relevant methodological modifications of TMEs regarding their use under temperate climatic conditions are necessary.

3. The approach of addition of saprophagous species can be handled with flexibility.

4. Increased soil microbial biomass under grass litter, and elevated nitrate concentrations in soil percolates from TMEs with $F$. macrophylla litter clearly indicate that the interaction between litter type and soil fauna does have a positive but transient effect on soil fertility. 


\section{Acknowledgements}

To the German Federal Ministry of Education and Research (BMBF), to the Conselho Nacional de Desenvolvimento Científico e Tecnológico (CNPq), and Embrapa Amazônia Ocidental, Brazil, for the financial support of the German-Brazilian cooperation in the SHIFT program, project ENV 52, of which this work was part of. We appreciate the field and laboratory assistance of Marcos Vinicius Torres de Brito (Pingo), the translation of the abstract made by Rainer Fabry.

\section{References}

AERTS, R. Climate, leaf litter chemistry and leaf litter decomposition in terrestrial ecosystems: a triangular relationship. Oikos, v.79, p.439-449, 1997.

ANDERSON, J.M.; PROCTOR, J.; VALLACK, H.W. Ecological studies in four contrasting lowland rain forests in Gunung Mulu National Park, Sarawak. 3. Decomposition processes and nutrient losses from leaf litter. Journal of Ecology, v.71, p.503-527, 1983.

ANDERSON, J.P.E.; DOMSCH, K.H. A physiological method for the quantitative measurement of microbial biomass in soils. Soil Biology and Biochemistry, v.10, p.215-221, 1978.

ARAUJO, Y.; LUIZÃO, F.J.; BARROS, E. Effect of earthworm addition on soil nitrogen availability, microbial biomass and litter decomposition in mesocosms. Biology and Fertility of Soils, v.39, p.146-152, 2004.

ARUNACHALAM, K.; SINGH, N.D.; ARUNACHALAM, A. Decomposition of leguminous crop residues in a "jhum" cultivation system in Arunachal Pradesh, India. Journal of Plant Nutrition and Soil Science, v.166, p.731-736, 2003.

ASHWINI, K.M.; SRIDHAR, K.R. Leaf litter preference and conversion by a saprophagous tropical pill millipede, Arthrosphaera magna Attems. Pedobiologia, v.49, p.307-316, 2005.

CHAUDHURI, P.S.; PAL, T.K.; BHATTACHARJEE, G.; DEY, S.K. Rubber leaf litters (Hevea brasiliensis, var. RRIM 600) as vermiculture substrate for epigeic earthworms, Perionyx excavatus, Eudrilus eugeniae and Eisenia fetida. Pedobiologia, v.45, p.796-800, 2003.

EDWARDS, C.A.; BOHLEN, P.J. Biology of earthworms. $3^{\text {rd }}$ ed. London: Chapman and Hall, 1996. 333p.

FEIGL, B.J.; SPARLING, G.P.; ROSS, D.J.; CERRI, C.C. Soil microbial biomass in Amazonian soils: evaluation of methods and estimates of pool sizes. Soil Biology and Biochemistry, v.27, p.1467-1472, 1995.

FÖRSTER B.; MUROYA, K.; GARCIA, M. Plant growth and microbial activity in a tropical soil amended with faecal pellets from millipedes and woodlice. Pedobiologia, v.50, p.281-290, $2006 \mathrm{a}$.
FÖRSTER, B.; EDER, M.; MORGAN, E.; KNACKER, T. A microcosm study of the effects of chemical stress, earthworms and microorganisms and their interactions upon litter decomposition. European Journal of Soil Biology, v.32, p.25-33, 1996.

FÖRSTER, B.; GARCIA, M.; SCHALLNASS, H. Respiration of soil invertebrates from temperate and tropical regions as measured by infrared gas analysis. Ecotropica, v.12, p.27-33, 2006 b.

FÖRSTER, B.; RÖMBKE, J.; KNACKER, T.; MORGAN, E. Microcosm study of the interactions between microorganisms and enchytraeid worms in grassland soil and litter. European Journal of Soil Biology, v.31, p.21-27, 1995.

FÖRSTER, B.; VAN GESTEL, C.A.M.; KOOLHAAS, J.E; NENTWIG, G.; RODRIGUES, J.M.L.; SOUSA, J.P.; JONES, S.E.; KNACKER, T. Ring-testing and field-validation of a Terrestrial Model Ecosystem (TME) - an instrument for testing potentially harmful substances: effects of carbendazim on organic matter breakdown and soil fauna feeding activity. Ecotoxicology, v.13, p.129-141, 2004.

GARCIA, J.A.; FRAGOSO, C. Influence of different food substrates on growth and reproduction of two tropical earthworm species (Pontoscolex corethrurus and Amynthas corticis). Pedobiologia, v.47, p.754-763, 2003.

GARCIA, M. Effects of pesticides on soil fauna: development of ecotoxicological test methods for tropical regions. Göttingen: Cuvillier, 2004. 281p. (Ecology and Development Series, 19).

GONZALEZ, G.; SEASTEDT, T.R. Soil fauna and plant litter decomposition in tropical and subalpine forests. Ecology, v.82, p.955-964, 2001.

HÖFER, H.; HANAGARTH, W.; GARCIA, M.; MARTIUS, C.; FRANKLIN, E.; RÖMBKE, J.; BECK, L. Structure and function of the soil fauna in Amazonian anthropogenic and natural ecosystems. European Journal of Soil Biology, v.37, p.229-235, 2001.

INTERNATIONAL ORGANISATION FOR STANDARDIZATION. ISO14240-1: soil quality - determination of soil microbial biomass - Part 1: substrate-induced respiration method. Geneva: ISO, 1997.

JÄNSCH, S.; GARCIA, M.; RÖMBKE, J. Acute and chronic isopod testing using tropical Porcellionides pruinosus and three model pesticides. European Journal of Soil Biology, v.41, p.143-152, 2005.

KAISER, E.A.; MUELLER, T.; JOERGENSEN, R.G.; INSAM, H.; HEINEMEYER, O. Evaluation of methods to estimate the soil microbial biomass and the relationship with soil texture and soil organic matter. Soil Biology and Biochemistry, v.24, p.675-683, 1992.

KAMPICHLER, C.; BRUCKNER, A.; KANDELER, E. Use of enclosed model ecosystems in soil ecology: a bias towards laboratory research. Soil Biology and Biochemistry, v.33, p.269-275, 2001.

KNACKER, T.; VAN GESTEL, C.A.M.; JONES, S.E.; SOARES, A.M.V.M.; SCHALLNASS, H-J.; FÖRSTER, B.; EDWARDS, C.A. Ring-testing and field validation of a Terrestrial Model Ecosystem (TME) - an instrument for testing potentially harmful substances: 
conceptual approach and studies design. Ecotoxicology, v.13, p.5-23, 2004.

KRATZ, W. The bait lamina test - general aspects, applications and perspectives. Environmental Science and Pollution Research, v.5, p.94-96, 1998.

KURZATKOWSKI, D.; MARTIUS, C.; HÖFER, H.; FÖRSTER, B.; BECK, L.; VLEK, P. Litter decomposition, microbial biomass and activity of soil organisms in three agroforestry sites in central Amazonia. Nutrient Cycling and Agroecosystems, v.69, p.257-267, 2004.

LEHMANN, J.; GÜNTHER, D.; SOCORRO DA MOTA, M.S. da; ALMEIDA, M.P. de; ZECH, W.; KAISER, K. Inorganic and organic soil phosphorous and sulfur pools in an Amazonian multistrata agroforetry system. Agroforestry Systems, v.53, p.113-124, 2001.

LINDAHL, B.D.; OLSSON, S. Fungal translocation - creating and responding to environmental heterogeneity. Mycologist, v.18, p.79-88, 2004.

LOUREIRO, S.; SAMPAIO, A.; BRANDAO, A.; NOGUEIRA, A.J.; SOARES, A.M. Feeding behaviour of the terrestrial isopod Porcellionides pruinosus Brandt, 1833 (Crustacea, Isopoda) in response to changes in food quality and contamination. The Science of the Total Environment, v.369, p.119-128, 2006.

MARTIUS, C.; HÖFER, H.; GARCIA, M.V.B.; RÖMBKE, J.; HANAGARTH, W. Litter fall, litter stocks and decomposition rates in rain forest and agroforestry sites in central Amazonia. Nutrient Cycling in Agroecosystems, v.68, p.137-154, 2004.

MARTIUS, C.; TIESSEN, H.; VLEK, P.L.G. The management of organic matter in tropical soils: what are the priorities? Nutrient Cycling in Agroecosystems, v.61, p.1-6, 2001.

MCMAHON, S.K.; WILLIAMS, M.A.; BOTTOMLEY, P.J.; MYROLD, D.D. Dynamics of microbial communities during decomposition of carbon-13 labeled ryegrass fractions in soil. Soil Science Society of America Journal, v.69, p. 1238-1247, 2005.

MONTEIRO, M.T.; GAMA-RODRIGUES, E.F. Carbono, nitrogênio e atividade da biomassa microbiana em differentes estruturas de serapilheira de uma floresta natural. Revista Brasileira Ciência de Solo, v.28, p.819-826, 2004.

MORGAN, E. Chemometrics: experimental design. Analytical chemistry by open learning. New York: John Wiley \& Sons, 1991.

MORGAN, E.; KNACKER, T. The role of laboratory terrestrial model ecosystems in the testing of potentially harmful substances. Ecotoxicology, v.3, p.213-233, 1994.
OFORI-FRIMPONG, K.; ROWELL, D.L. The decomposition of cocoa leaves and their effect on phosphorus dynamics in tropical soil. European Journal of Soil Biology, v.50, p.165-172, 1999.

POBOZSNY, M.; GONZÁLEZ, O.R.; RODRIGUEZ, M.E. The role of Trigoniulus lumbricinus Gerst. (Diplopoda) in the decomposition of leaf litter in some plant communities of Cuba. Opuscula Zoologica Budapest, v.25, p.89-93, 1992.

RÖMBKE, J.; FÖRSTER, B.; JÄNSCH, S.; SCHEFFCZYK, A.; GARCIA, M. Terrestrische ökotoxikologische Testmethoden für die Tropen. Teil 1: Labortests mit Regenwürmern und Arthropoden. Umweltwissenschaften und Schadstoff-Forschung, v.17, p.20-27, 2005a.

RÖMBKE, J.; FÖRSTER, B.; JÄNSCH, S.; SCHEFFCZYK, A.; GARCIA, M. Terrestrische ökotoxikologische Testmethoden für die Tropen. Teil 2: Halbfreiland- und Freilandtests sowie Risikobeurteilung. Umweltwissenschaften und Schadstoff-Forschung, v.17, p.85-93, 2005b.

RÖMBKE, J.; HANAGARTH, W.; HÖFER, H.; GARCIA, M.; MARTIUS, C. Feeding rates of soil organisms at four different forest sites in Amazonia. Journal of Tropical Ecology, v.22, p.313-320, 2006.

RÖMBKE, J.; MELLER, M.; GARCIA, M. Earthworm densities in central Amazonian primary and secondary forests and a polyculture forestry plantation. Pedobiologia, v.43, p.518-522, 1999.

SHEPPARD, S.C. Toxicity testing using microcosms. In: TARRADELlaS, J.; BITTON, G.; ROSSEL, D. (Ed.). Soil ecotoxicology. Boca Raton: Lewis, 1997. p.345-373.

SHUKLA, S.C.; TRIPATHI, S.P. Water relations of millipede Trigoniulus lumbricinus (Gerstacker). Journal of Advanced Zoology, v.6, p.55-58, 1985.

SWIFT, M.J.; HEAL, O.W.; ANDERSON, J.M. Decomposition in terrestrial ecosystems. Oxford: Blackwell Scientific, 1979. 372p.

TIAN, G.; KANG, B.T.; BRUSSAARD, L. Biological effects of plant residues with contrasting chemical compositions under humid tropical conditions - decomposition and nutrient release. Soil Biology and Biochemistry, v.24, p.1051-1060, 1992.

VAN VORIS, P.; TOLLE, D.A.; ARTHUR, M.F. Experimental terrestrial soil-core microcosm test protocol: a method for measuring the potential ecological effects, fate, and transport of chemicals in terrestrial ecosystems. Richland: Pacific Northwest National Laboratory, 1985. (Technical Report).

VON TÖRNE, E. Assessing feeding activities of soil living animals. I. Bait-lamina test. Pedobiologia, v.34, p.89-101, 1990.

Received on November 13, 2008 and accepted on July 2, 2009 